number of weeks represented and entitlement to unemployment benefit was off-set accordingly.

The change in policy results from a review undertaken by the Social Security Commission. From 1 October 1980 redundancy payments will not be set-off against entitlement to unemployment benefit.

\title{
HAS THE NEXT BUS GONE YET?: INDUSTRIAL RELATIONS IN THE 1980s
}

\section{FJL YOUNG*}

This title was drawn from the punch line in one of those Irish stories which still creep into local publications despite the Human Rights Commission. Paddy's query on arriving at the bus stop (the writer argues) seems to summarise much current concern about industrial relations.

\section{AGITATORS AND INDUSTRIAL CONFLICT}

A widespread view is that many of New Zealand's industrial ills can be traced to the presence of a few agitators. The Sofinsky Case notwithstanding, such a view cannot go unchallenged. It is hard to conceive how 150 (or even 1500) people can upset New Zealand's democratic, egalitarian society unless that society is far from well. The writer consequently is not alone in drawing attention to the comments of the industrial relations adviser in the Prime Minister's Department. Dr Turkington writes:

"There are a number of difficulties with the 'agitator argument'. First, whether one labels a person an agitator depends very much on one's view of the nature of the enterprise. Management may regard leaders of workers in conflict situations as 'agitators', while the workers themselves may regard them as anything but. Second, and aside from the problem of definition, the argument fails to explain how a few 'militants' can infiltrate otherwise peaceful groups of workers and lead them into conflict action. In other words, it does not adequately explain why agitators exist in the industry and why they are apparently successful."'1

Later in the same work, in a very careful analysis of the multiplicity of causes of conflict in the meat freezing industry, on major construction sites and on the wharves, Dr Turkington comments:

"It seems the 'agitator argument' has minimal explanatory value by comparison with more basic factors."

Experts have long pointed to certain facts about industrial conflict. Some environments are particularly prone to conflict le.g. motor assembly plants and meat freezing). Others are relatively peaceful (e.g. banking and retailing). The environment, however, need not be the deciding factor in determining whether or not open conflict occurs. The capacity of the parties to handle the inherent conflict in an employment relationship is generally much more important. Even a stoppage-ridden industry can still have enterprises which are rarely (if ever)

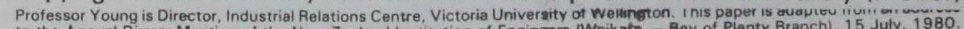
to the Annual Dinner Meeting of the New Zealand Institution of Engineers (Waikato - Bey of Plenty Branch), 15 July, 1980.

1 Turkington, D.J. (1976) Indusirial conflict Wellington, Methuen. p. 119.

2 Turkington, ibid. D. 319

58 
involved in disputes. ${ }^{3}$ The inference would seem to be that joint problem solving is a key industrial relations skill. Joint problem solving, however, presupposes that those involved are able and willing to work their way through some pretty difficult issues to achieve mutual accommodation.

Joint problem solving is very evident in some European approaches to worker participation in management (e.g. co-determination in West Germany and shop floor democracy in Sweden). In each case it is associated with a very sophisticated approach to negotiating industrial matters. A similar foundation is lacking in this country. The highly controlled form of industrial negotiation practised here, in the writer's view, inhibits innovation in industrial relations. This is likely to be a substantial obstacle to the improved industrial relations essential to restructuring our economy.

\section{PROPERLY DEVELOPED INDUSTRIAL NEGOTIATION}

The average person seems to think of industrial negotiation in terms of wage fixing and the control of stoppages. Properly developed industrial negotiation extends beyond this. It is essentially a 'political' relationship turning on the exercise of power, authority and influence. It follows that industrial negotiation cannot take place between an employer and individual workers. It must be a relationship between organisations (and for that reason should be more properly called collective bargaining). Here the exercise of power becomes important. Unless each party faces the ultimate possibility of industrial action by the other there is little pressure for agreement.

What is involved in collective bargaining is a process of accommodation between employers and trade unions. This has been described "as a way of organising divergent interests in such a way as to resolve rather than extend open conflict". ${ }^{4}$ As such it involves more than negotiating a collective agreement (or an award). That agreement is effectively a peace treaty for a fixed period. No treaty, however, is worth the paper on which it is written unless it is properly enforced. Consequently, the process of industrial negotiation does not end with the signing of a collective agreement. It shifts from negotiation to dayto-day administration and interpretation of the agreement. That is essentially workplace activity and workplace activity which builds up the capacity for more sophisticated types of joint problem solving.

What has just been described is a much more open approach to industrial negotiation than that formally practised in New Zealand. Could it work here? Would its adoption merely add to what some people already regard as unacceptably high levels of industrial conflict? No one can give firm and absolutely unequivocal answers to these questions. There is no industrialised country in which stoppages and wildcat actions never occur. There are nonetheless a number of industrialised countries whose standing in 'the stoppage league" shows a much better performance than New Zealand. Their experience does point to a common core of good industrial relations practice with the potential to transform collective bargaining. From a clash between warring factions it can become a tough but positive problem solving exercise involving the parties and, where necessary, government. Polarisation, distrust, and outright bad faith can be made to give way to tough, but fair-minded negotiation based on good faith.

3 The Turkington study (p. 217) gives an example of this. In the meat freezing industry between 1967 and 1973 four of the works were involved in only two stoppages each over the whole period. A total of 14 works averaged less than one stoppage

4 Der year. Four, however. averaged between five and ten stodpades annually.
Kornhauser, A., R. Dubin and A. Ross (Eds) (1954) Industrial Conflict McGraw-Hill. p. 271.29 


\section{GOOD FAITH IN INDUSTRIAL RELATIONS}

The concept of good faith is quite crucial here. It has obvious ethical roots way back in Western civilization, but has a rather specific meaning in industrial relations practice. Broadly speaking it means acceptance of the other party and willingness to abide by established procedures in industrial negotiation. In more detail it means willingness to meet the other party with an open mind at reasonable times; willingness to study the other party's arguments and to admit merit in them where it exists; willingness to disclose all relevant information; willingness to safeguard confidentiality; willingness to accept "give and take" in order to reach a solution fair to both sides; and willingness to honour agreements reached and to accept a referee on points of interpretation and application. Good faith in industrial relations also requires mutual respect even when expressing conflicting points of view. All this requires the parties to forego short term advantages which can only create distrust and polarised attitudes. Some examples drawn from close to home may illustrate why good faith is important:

- a trade union negotiated a new industrial agreement with employers in an industry. Within two weeks of signing the agreement, it brought pressure to bear on one of the employers to pay a higher rate. Without consulting the other employers, this employer conceded the higher rate. Both union and employer acted in bad faith and created widespread distrust throughout the industry.

- pressure of work in a certain organisation led to a gradual breakdown of established communications and disputes procedures. Eventually a dispute arose concerning the application of an award provision to a particular employee. Initially the employer refused to meet with local trade union representatives and their national officials to discuss the matter. As the dispute hotted up, he attempted to meet the local representatives but not the national officials. When he eventually conceded the initial claim, he still faced a greater conflict as he sought to avoid discussions with the national officials.

- a trade union sought to compel an employer to hire its members to the exclusion of other workers who would have qualified for at least some of the work involved. It attempted to avoid the statutory prohibition on such behaviour by applying muscle to the employer's supervisors. They were "requested" to hire only persons who produced written evidence of union membership.

Each of these illustrations contains two elements which work against joint problem solving in an atmosphere of good faith : an overbearing attitude towards the apparently weaker party and failure or refusal to comply with procedures laid down by the community or dictated by common sense. Unfortunately such behaviour is sufficiently widespread to set at risk the efforts of many people who are currently trying to improve the climate of industrial relations. Furthermore, unless such behaviour can be changed, the possibility of coping with both inflation and the restructuring of the economy is questionable.

One of the principal beliefs of democratic society is that undesirable conditions can be removed by legislation. The establishment of community standards by statute is seen as the route to improved human behaviour. Practical experience shows that this is not always true. Legal rules can only be effective 60 
in democracies when they have substantial comunity support. Racism and sexism, for example, may be outlawed by statute, but they will certainly not disappear without patient education and experience of their irrelevance. It is the process of education and experience which reformulate community standards and not the passage of a law. If an issue is relatively simple, the processes of education, experience and legislation may be relatively fast (even occuring almost simultaneously). With complex issues, like many industrial relations problems, the matter is not so easily resolved. There is a degree of over-kill as legislators seek to enforce rules which are out of step with relevant sections of public opinion.

A good example of this type of over-kill lies in the recent controversy over compulsory unionism. Vocal public opinion seemed to politicians, and even to some uncommitted observers, to favour abandonment of unqualified preference. Ballots taken after the statute had been amended showed how wide of the mark this was. ${ }^{5}$ Much the same, in the writer's opinion, is true of the massive intrusion of penalties into industrial law in recent years. They are ineffective because the parties involved view them as largely irrelevant.

\section{IMPORTANT PRINCIPLES AND PRACTICES}

What has this got to do with earlier comments about joint problem solving and negotiation in good faith? Here the study of comparative industrial relations, industrial relations in different countries, can be instructive. Certain principles and practices appear with remarkable regularity where industrial relations is not regarded as a running sore:

- it is accepted that mutual recognition is essential if the parties are to develop an orderly, stable relationship. This may be done on a voluntary basis (as in the Swiss Peace Agreement or the Norwegian Basic Agreement) or it may be enforced through state intervention (through certification in the United States and Canada);

Registration in New Zealand certainly embodies the principle under discussion here. The European and North American practices just mentioned develop it in more detail with procedures and/or extensive tests to demonstrate the good faith of the parties involved.

- it is accepted that the parties themselves, not the law-makers, should determine what constitutes industrial matters even if on occasions this results in a stoppage. This permits the parties to tailor their relationship to suit the infinite variety of technological, economic and cultural constraints found in particular workplaces even within the same industry. Sometimes this approach is modified slightly in the interests of orderly relationships. The central organisations of the parties may agree to standard rules for handling disputes throuchout industry (Scandinavia). Alternatively the state may require every collecuive agreement to include a grievance procedure (Canada). These modifications, however, do not depart from the general principle that industrial matters should be determined by the parties themselves.

In New Zealand, industrial matters are, of course, narrowly defined by statute and judicial interpretation. The advantage of the less restrictive overseas approaches, to the writer, lies in the fact that they encourage the parties to develop a vested interest in the non-legal aspects of their relationship. This 5 The voting pattern indicated that the overwhelming majority of employees wished to retain unqualified preference. 
shifts the emphasis in negotiation towards joint problem solving of practical issues.

- it is accepted that mutual recognition and freedom to determine industrial matters carry with them certain obligations towards the community. Every effort must be made to minimise stoppages over unresolved disputes of interest. Stoppages over an alleged breach of collective agreement (or its interpretation) must not take place.

In this whole area there are a variety of approaches. Unresolved disputes of interest may generally be left to settlement through a stoppage provided the parties meet their statutory obligation to negotiate in good faith (the United States). Alternatively, varying degrees of voluntary or obligatory mediation may be employed to achieve a settlement (Canada, Scandinavia and Switzerland). In the case of disputes of right, by way of contrast, unresolved issues are invaribly settled by some form of enforceable adjudication. This experience contrasts markedly with New Zealand where something like $75 \%$ of stoppages are in breach of agreement and involve disputes of right. ${ }^{6}$

The principles and practices just reviewed are tied together by a common thread. They are seen by the parties involved as acceptable and relevant to their relationship. They meet standards of fairness and practicality which are crucial in industrial relations. No realist can expect the parties involved in industrial relations to see eye-to-eye. In some cases they will actively dislike each other. In others, experience can teach them to respect and even admire each other without surrendering their own principles. In the latter situation they can reach a shared understanding (but not shared objectives) about the realities of industrial relations. They become "professionals".

This theme of professionalism does seem to be surfacing more frequently in discussions of New Zealand's industrial climate. The New Zealand Economist, for example, recently stressed that the legal framework is only part of the problem. It concluded a discussion of "the behavioural framework" of industrial relations thus

"There is no law that will ensure good industrial relations. And you cannot legislate against arms length relationships and bad manners."

\section{INDUSTRIAL RELATIONS IN THE 1980 S}

Those words highlight some of the industrial relations problems likely to be encountered as the economy is restructured in the 1980 s. Recruiting and training people to build and operate the new energy projects are likely to strain the community's imagination and facilities. They may well be made much more difficult because of the sensitivity of relativities and continuing attempts at centralised wage fixing. And those issues in turn may be further complicated by the need to encourage some selective immigration in the face of continuing unemployment. On top of all this come the challenges and fears raised by the micro-processor and other new technologies.

Do these problems mean that the industrial climate of the 1980 s must inevitably be one of conflict and frustration? Provided the community is prepared

6 In part this situation springs from the statutory definitions of disputes of interest and disputes of right. They are so draited as to preclude the easy resolution of matters arising during the currency of a collective agreement or an award. American, Scandina.

vian and Swiss practices cover this particular problem.

New Zealand Economist, April 1980 , pp. 12 and 43.

62 
to think in terms of social innovation, the outcome could be totally different and overwhelmingly positive. The development of New Zealand forms of joint problem solving and negotiation in good faith could help create such an atmosphere. It could have a greater impact upon the industrial community than the early years of industrial conciliation and arbitration.

In the last decade, there have been national and international debates on industrial democracy and the quality of working life. There has been considerable disagreement about concepts and objectives, but theorists and practitioners do seem to agree about one matter. Commitment to creating a better working environment and more imaginative job design can (but will not necessarily) improve industrial attitudes. Where success has been achieved, it has required the type of joint problem solving discussed here. This has transcended national boundaries and negotiating structures (be they industrywide or enterprise specific). The approach too snows signs of growth in New Zealand. The New Zealand Employers Federation's concern for employee involvement points to a significant shift towards these concepts. The case studies published by the Federation raise many of the issues and problems encountered overseas, but more importantly point to "home grown" solutions.

\section{THREE GUIDELINES}

The importance of home grown solutions cannot be emphasised too strongly. Restructuring the economy and coping with new technologies cannot be left to overseas experts or slavish copying of overseas models. The country has to live with the solutions and thus has to find realistic solutions relating to the world in which it lives. In this respect, three guidelines may be suggested for use in developing industrial relations policies and practices in the 1980s :

- agreed solutions for restructuring the economy and the introduction of new technologies are in the long term interests of all New Zealanders. The potential for conflict lies in short term problems.

The interests of the community and the new or innovating enterprises may clash with the expectations of those whose livelihood and jobs are threatened. Agreement on the phased introduction of change consequently seems vital to minimise human costs and gain acceptance of new ways.

- "investment in adaptation" needs to be encouraged throughout the community. A positive response is likely if people can see advantage in responding to change. Policies encouraging adjustment to change thus need to anticipate rather than follow events.

- the costs and benefits of restructuring the economy and using new technology are likely to accrue to different groups of people. The community and the new or innovating enterprises gain. Those who are displaced lose. The costs to the losers ought to be deducted from the benefits to those who gain.

The readjustment package ${ }^{8}$ recently announced for workers adversely affected by the textile industry plan is an example of this type of policy. Its narrowness (in the sense of being industry specific) and its timing nonetheless raise questions about optimum effectiveness. This writer, personally, is in favour of more broadly based anticipatorv active employment pulicy. wovering Sucn inaturs as assistance with local and long distance job search, training or retraining and relocation of displaced
workers. 
In developing these guidelines, no reference has yet been made to wages policy. this has been quite deliberate. It is argued that the institutional foundation of industrial relations (its organisation, the structure and attitudes of the parties) must first be accepted as relevant and fair. Until that is the case, the development of an acceptable wages policy is likely to be no more than "exhortation in a vacuum".

The guidelines just advanced are designed to assist in adjusting to changed circumstances. The overall objective of adjustment is the improved well-being of the community as a whole. As this is achieved, the political problem of distributing the gains will become very apparent. Who gets what share (consumers, producers and the state)? That distributional problem is, however, already present. Failure to resolve it is likely to limit the possible gains from a restructured economy and intelligent use of the new technologies.

It is hard to see how the distributional problem can be resolved without considerable social innovation. Improved productivity on the scale required calls for something more than massive investment (and consequent restraint on consumption). The capital equipment involved must be used effectively by people who understand what they are doing and who are committed to their tasks. This is essentially a workplace issue involving joint problem solving. It also requires attention to appropriate incentives and margins for skill. Here the potential for a clash between the need for innovation and traditional attitudes is severe. Its resolution is likely to require a close look at what the community. means by "egalitarianism"

\section{CONCLUSION}

It would be useful to have the benefit of hindsight from the year 2010 . As that is not possible, one can only guess at the verdict of history. At the moment, New Zealand is probably completing its movement into modern industrial society. The shift from pastoral colony to modern industrial state will have been completed in less than an average life-time. Current conflicts and strains over attitudes and traditions are thus to be expected. There is nevertheless a great advantage in being a late-comer to the industrial stakes. Observation of the experience of other runners can provide significant pointers about tracks to follow and obstacles to avoid.

The lessons of comparative industrial relations point to the importance of encouraging the parties to solve their own problems in good faith. This is reinforced by national and international experience in "employee involvement". The role of the state in industrial relations may consequently have to shift from detailed regulation into two other areas : the encouragement of industrial selfgovernment and greater involvement in adjustment (economic and technological change). This would need to be accompanied by a widening of the scope of industrial negotiation and close attention to the observance of collective agreements (and awards). Such a change need not dismantle our traditional approach to industrial relations but it would modify it in the light of the needs of the late 20th century. Those needs include community acceptance of the fact that the motivation to work involves something more than a monetary exercise. Employees have (and should be encouraged to have) interests in their workplace beyond the pay packet.

All this is easily said but not so easily achieved. The danger lies in not attempting to meet the challenge - in arriving at the bus stop after the next bus has gone.

64 